\title{
Trait-based evaluation of plant assemblages in traditional farm ponds in Korea: Ecological and management implications
}

\author{
Sungsoo YOON, ${ }^{1}$ GoWoon KIM, ${ }^{2}$ Ho CHOI, ${ }^{3}$ Chaeho BYUN,,${ }^{4}$ Dowon LEE ${ }^{*}$ \\ ${ }^{1}$ Climate Change and Agroecology Division, National Institute of Agricultural Sciences, Rural Development Administration, 166 \\ Nongsaengmyeong-ro, Iseo-myeon, Wanju-gun, Jeollabuk-do 55365; ${ }^{2}$ O-Jeong Eco-Resilience Institute (OJERI) \& Division of \\ Environmental Science and Ecological Engineering, Korea University, 02841 Seoul; ${ }^{3}$ Department of Biology Education, Seoul National \\ University, Gwanak-ro 1, Gwanak-gu, Seoul 08826; ${ }^{4}$ School of Civil and Environmental Engineering, Yonsei University, Yonsei-ro \\ 50, Seodaemun-gu, Seoul 03722; ${ }^{5}$ Department of Environmental Planning \& Asian Center, Seoul National University, Gwanak-ro 1, \\ Gwanak-gu, Seoul 08826, Republic of Korea
}

\begin{abstract}
The Korean traditional farm pond called dumbeong is an important rural landscape element that supports local biodiversity and is useful in irrigating agricultural fields during dry periods. This study assesses how plant communities in dumbeongs respond to adjacent land use, water depth, open-water surface, and nutrient levels and irrigation usage. Plant functional and species groups, based on trait and species data respectively from 20 dumbeongs in Seocheon-gun, South Korea, were classified by hierarchical analysis and nonmetric multidimensional scaling. Relationships between the plant community composition and explanatory variables at both the species and functional group levels were tested through redundancy analysis. The results showed that irrigation usage prevented nutrient accumulation and water depth reduction of the ponds, and we found water depth was the only significant factor that determined plant composition at both species and functional group levels. The plant functional groups were more useful than plant species in predicting plant composition in dumbeongs, owing to their collective response to water depth and open-water surface. Our results demonstrate that management practices of dumbeong, such as periodic drainage, sediment removal and control of dominant plant species, alter its plant communities and thus need to be considered for biodiversity conservation in agricultural landscapes.
\end{abstract}

\section{INTRODUCTION}

Wetland ecosystems provide important ecological services by capturing nutrients and supporting biodiversity (Hansson et al., 2005). Agroecological land uses that embrace wetlands can help to prevent rural biodiversity loss associated with agricultural intensification (Benton et al., 2003; Michel et al., 2007). Farm ponds, despite their small size and isolation, are important in supporting biodiversity in agricultural landscapes (Williams et al., 2004; Oertli et al., 2005; Casas et al., 2012), and quantitative and theoretical

Corresponding author: leedw@snu.ac.kr

Key words: Pond ecology; irrigation; plant composition; plant functional group; trait; biodiversity.

Edited by: Rossano Bolpagni, University of Parma, Italy.

Received: 30 September 2018.

Accepted: 28 December 2018.

This work is licensed under a Creative Commons Attribution NonCommercial 4.0 License (CC BY-NC 4.0).

CC Copyright S. Yoon et al., 2019

Licensee PAGEPress, Italy

J. Limnol., 2019; 78(1): 92-106

DOI: 10.4081/jlimnol.2019.1861 studies have discussed the ecological values of ponds as habitats in terms of biological diversity (Downing and Leibold, 2002; Downing, 2005; Gioria et al., 2010; Santi et al., 2010; Landi et al., 2012; Zhang et al., 2015).

The Korean traditional farm pond dumbeong, meaning "a puddle," is particularly useful in dry periods as a secondary water source for rice paddy fields. It is constructed by digging a small pit $\left(<500 \mathrm{~m}^{2}\right)$ in the marginal areas of agricultural fields where water collects (Tab. S1). A dumbeong enhances farm biodiversity by providing habitat for various organisms (Kim et al., 2011; Choe et al., 2013, 2016). However, with the adoption of mechanized irrigation and agricultural intensification practices, dumbeongs are coming into disuse (Huang et al., 2012).

Dumbeongs are situated in landscapes that are impacted by the anthropogenic forces of habitat degradation, water pollution, and hydroperiod alteration which are factors that affect plant communities in ponds (Wood et al., 2003; Edvardsen and Økland, 2006; Deegan et al., 2007). Land use in adjacent areas has been studied to be significantly associated with the deterioration of water quality in ponds, affecting plant species diversity (Søndergaard et al., 2005; Declerck et al., 2006; Akasaka at al. 2010; Alahuhta and Aroviita, 2016). Periodic pond drainage and low fish density have been seen to facilitate diverse plant taxa (Lemmens et al., 2013), and sediment removal coupled with periodic drainage can be a strategy to mitigate the loss of wetland plant species of high 
conservation value (Sayer et al., 2012). Numerous studies have discussed the effects of anthropogenic disturbances on ponds, nonetheless the relationship between anthropogenic activities and plant composition of farm ponds remains unclear, as the interacting environmental variables are complex (Gallego et al., 2014; Hassall and Anderson, 2015). Some studies have concluded that the variation in the composition of pond plant communities is due to stochastic events including both natural and anthropogenic factors (Del Pozo et al., 2010; Sayer et al., 2012; Hassall and Anderson, 2015).

Focusing on traits measured at the individual level instead of plant species can help to reduce uncertainty in the multi-layered analysis of biodiversity in ponds (McGill et al., 2006). The study of functional traits is a method to distinguish between selective and random processes by detecting co-occurring species in the functional trait space when a community responds to disturbances (Villéger et al., 2011; Mouillot et al., 2013). A functional group can be composed of species with similar traits that reveal an assembly rule (Keddy et al., 1992). This integration of species and trait data can be useful to identify specific groups of plant species along with the environmental gradient in ponds.

The studies of the composition of plant communities in dumbeongs on the basis of functional traits can help to understand biodiversity and ecosystem functions, and inform conservation decisions for dumbeongs. In doing so, functional groups may provide focused insights for the patterns of plant communities in dumbeongs, whose environments are affected by management practices. Hence, our study has three objectives: i) identify appropriate functional groups of plant species in selected dumbeongs to predict plant composition using explanatory variables, ii) compare the explained variation of species-based composition to that of functional groupbased composition, and iii) understand the relationship between management and plant compositions.

\section{METHODS}

We investigated 20 dumbeongs in Seocheon, South Korea, located in the downstream area of Geumgang Basin (Fig. 1). The area of Seocheon is about $400 \mathrm{~km}^{2}$, of which $40 \%$ is covered with forest and $29 \%$ with rice paddy fields (National Geographic Information Institute, 2014). The annual mean temperature and precipitation are $12.3^{\circ} \mathrm{C}$ and $1349.2 \mathrm{~mm}$, respectively (Seocheon County, 2016). Many dumbeongs in Seocheon have been destroyed due to the introduction of mechanized irrigation and the expansion of arable lands. Most of the remaining dumbeongs are permanent ponds located in or near valleys, which hinders their conversion to other land uses. The investigated dumbeongs in Seocheon share three key characteristics: they were originally constructed to provide water to crop fields and have been managed by private owners, and they are $<500 \mathrm{~m}^{2}$ in area (Tab. S1). As rice paddy fields have gradually been abandoned and irrigation methods have changed, only 13 of the 20 dumbeongs investigated are still used for irrigation. The others are used as fish ponds or have been abandoned.

The percentage of plant cover was visually estimated by two experts through a complete survey. Whole plants covering the water surface and an area including a $10 \mathrm{~cm}$ buffer boundary of land from the shore line of the dumbeong were sampled. The buffer boundary was set to uderstand the influence of water regime on plant cover of bank. It is noted that the water level of dumbeoungs had not significantly changed due to no rain since it was fully restored in spring. The dumbeongs were not divided into quadrats because the plants were primarily distributed in relatively small areas. The plant cover data were assigned to six classes of the mid-point cover (i.e., $<1 \%$ estimated as $0.5 \%,<5 \%$ as $3 \%,<25 \%$ as $14 \%,<50 \%$ as $37.5 \%$, $<75 \%$ as $62.5 \%$, and $>75 \%$ as $87.5 \%$ ) to reduce bias in the subjective estimation. The plant data were collected in August 2016 - the peak period of plant cover for the year.

Three types of land use data, including agricultural land (Agri), forest (Forest), and freshwater (Water), were extracted from a digitized map (National Geographic Information Institute, 2014), using the ArcGIS version 10.1 (ESRI, Redlands, CA, USA). The proportion of 3 land use types for areas within a radius of 100 or $200 \mathrm{~m}$ from the dumbeong edges was calculated to extract six land use variables (Agri100, Agri200, Water100, Water200, Forest100, and Forest200), the extents of which were set to avoid spatial autocorrelation among the dumbeongs. Land covers of human settlement and road were not evaluated as those were a little varied and far from dumbeongs. Studies have reported that adjacent land uses in those ranges influenced vegetation structure and water properties in farm ponds (Declerck et al., 2006; Akasaka et al., 2010). The boundaries of dumbeongs were set as waypoints and were tracked by using a global positioning system (GPS) device (Garmin 60CSx, Olathe, KS, USA), and the surface area was calculated using GIS software (QGIS 2.10.1 Pisa). The mean depth was calculated from the measurements obtained at 1 and $2 \mathrm{~m}$ from the land-water interface every $2 \mathrm{~m}$ along the long axes of the ponds using a meter stick. We chose these sampling points because all types of mesohabitats (defined by different types of dominant vegetation and areas of open-water surface) were included in this range.

The area of open-water was recorded as percent of the total dumbeong area, and defined as the surface area without vegetation, except for the coverage by woody plants above $1 \mathrm{~m}$ from the water surface and by submerged plants. As the area of open-water was also 
visually estimated by two observers, it was transformed into the mid-point cover following an approach similar to that of the plant data. Water samples were obtained on the same date as the vegetation survey in August 2016. The electric conductivity (EC) was measured in situ by specific conductance using handheld probes (Model 30; YSI, Yellow Springs, OH, USA). The water samples were collected by submerging a clean plastic bottle in the open-water to a depth of $20 \mathrm{~cm}$. When the depth was less than $20 \mathrm{~cm}$, the surface water was collected carefully to avoid the inclusion of substratum materials. We measured pH with an automatic titration device (877 Titrino Plus; Metrohm, Herisau, Switzerland) in laboratory before the water samples were filtered using a $250-\mathrm{mL}$ vacuum filter/storage bottle with a $0.45-\mu \mathrm{m}$ cellulose acetate membrane (Corning Inc., Corning, NY, USA). The concentration of major cations and nutrient ions was determined in the laboratory by ion chromatography (ICS-1600; Dionex, Sunnyvale, CA, USA). The concentration of dissolved organic carbon (DOC) and total dissolved nitrogen (TN) was measured using a Shimadzu analyzer (TOC-VCPH with unit TNM-1; Shimadzu Co., Kyoto, Japan).

We collected data on irrigation usage through interviews with pond owners in July and August 2016. As the aim of this study was to determine the influence of management practices on plant compositions in the dumbeongs, based on the interviews and findings of previous studies we categorized the dumbeongs into two types according to their irrigation usage: dumbeongs where the sediment was removed regularly for the past five years (irrigation, IR), and dumbeongs that were not maintained in this way (non-irrigation, NIR). A five-year period was considered as it is the minimum required for ecosystem development for the newly constructed ponds to perform a steady ecosystem function (Mitsch and Wilson, 1996). Planting, removal of vegetation, usage of biocides, and fish breeding were also documented by interviewing the owners and conducting field surveys.

Seven types of plant traits were selected in the light

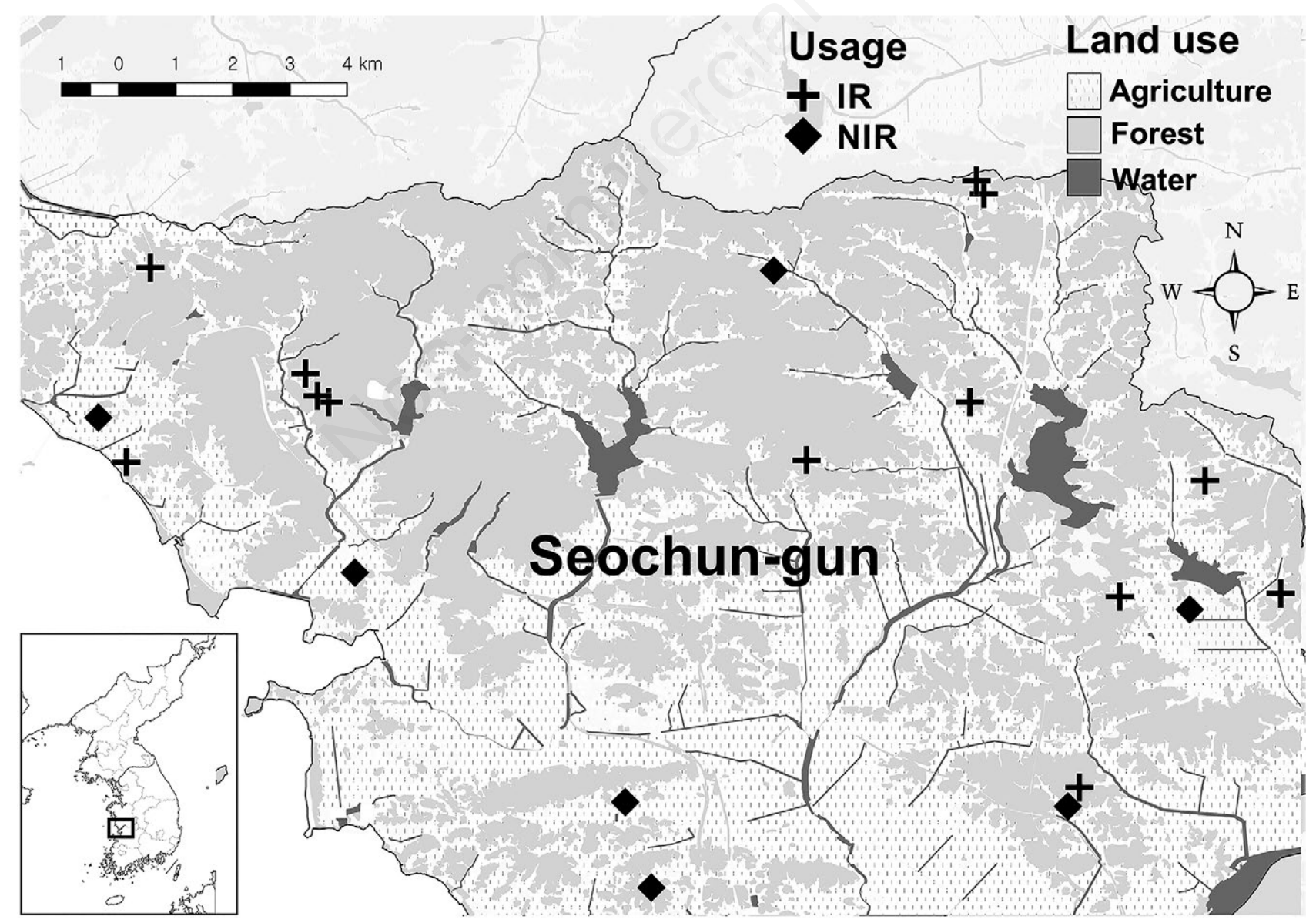

Fig. 1. Locations of the 20 dumbeong study sites in Seocheon, Korea. IR, ponds used for irrigation regularly in recent 5 years; NIR, ponds not used for irrigation for more than 5 years. 
of literature review and advice of wetland experts (Tab. 1). The trait data were collected from online databases (Kühn et al., 2004; Kleyer et al., 2008; Kattge et al., 2011; Laboratory of Wild Plant Science, 2014; USDA/NRCS, 2014; eFloras, 2016; Korea National Arboretum, 2016), literature searches (Morishima and Oka, 1976; Van et al., 1976; Raven, 1992; Gichuki et al., 2001; Katori et al., 2002; Choung et al., 2012; Cho et al., 2013), and field surveys. Hierarchical cluster analysis was used to classify 37 plant species found in the dumbeongs into functional groups by generating a dendrogram. The Ward method and squared Euclidean distance were selected from the options available in SPSS ver. 20.0 (IBM, Armonk, NY, USA). The cutting point of the dendrogram was chosen to include at least three species characterized by particular traits in each functional group.

As all trait data were binary, parametric methods such as ANOVA were not used to detect the traits that can separate species into distinct functional groups. Instead, significant differences in trait composition among the functional groups were calculated using the analysis of similarities (ANOSIM). Differences among the functional groups were described and visualized by computing the non-metric multidimensional scaling (NMDS) ordination with fitted vectors of traits from species-trait data matrix using the metaMDS and envfit functions of the vegan package in the R statistics software (Oksanen et al., 2016).

The statistical analyses were performed using standardized variables (Z-score), and the plant community data were log-transformed to reduce inequality of variances. The correlation between explanatory variables was tested by Spearman rank correlation test. MannWhitney $U$-test was performed to test the differences in environmental and land use variables between the management types. The principal component analysis (PCA) was used to explore the patterns of water chemistry and adjacent land use variables among the dumbeongs. The PCA reduces the number of correlated variables, thus avoids the multicollinearity problem.

The redundancy analysis (RDA) was performed to reveal the effect of explanatory variables on the composition of plant communities of the dumbeong. The RDA is a constrained ordination method that tests the linearized relationship between a set of response and predictor variables (Legendre and Legendre, 2012). The RDA was used to evaluate the effects of environmental and spatial variables on the species and functional group composition, respectively. The RDA results provide visualized propensities of individual species or functional groups for specific predictors. The RDA model is constructed using the stepwise both-selection method. Statistical significance was tested using a randomized permutation test. All statistical analyses were performed using the $\mathrm{R}$ statistics software ( $\mathrm{R}$ Development Core Team, 2016) and SPSS ver. 20.0 (SPSS Inc, Chicago, IL, USA).

Tab. 1. Summary of the selected plant traits.

\begin{tabular}{|c|c|c|}
\hline Trait & Category & Description \\
\hline Life history & $\begin{array}{l}\text { Annual } \\
\text { Perennial }\end{array}$ & $\begin{array}{l}\text { Lifespan: } 1 \text { year } \\
\text { Lifespan: }>2 \text { years }\end{array}$ \\
\hline Aquatic plants morphology & $\begin{array}{l}\text { Emergent } \\
\text { Floating-leaf } \\
\text { Floating } \\
\text { Submerged }\end{array}$ & $\begin{array}{l}\text { Leaves and stems pierce the water surface } \\
\text { Floating leaves and rooting to ground } \\
\text { Floating leaves and rooting in water } \\
\text { Growing entirely underwater }\end{array}$ \\
\hline Vegetative propagation & $\begin{array}{l}\text { Below } \\
\text { Above }\end{array}$ & $\begin{array}{l}\text { Propagate by below ground (e.g., rhizome) } \\
\text { Propagate by above ground (e.g., stolon, frond fragmentation) }\end{array}$ \\
\hline Wetland indicator status & $\begin{array}{l}\text { OBL } \\
\text { FACW } \\
\text { FAC } \\
\text { FACU } \\
\text { UPL }\end{array}$ & $\begin{array}{l}\text { Wetland occurrence: }>99 \% \\
\text { Wetland occurrence: } 67 \% \sim 99 \% \\
\text { Wetland occurrence: } 34 \% \sim 67 \% \\
\text { Wetland occurrence: } 34 \% \sim 1 \% \\
\text { Wetland occurrence: }<1 \%\end{array}$ \\
\hline Seed morphology & $\begin{array}{l}\text { Balloon } \\
\text { Elongated } \\
\text { No appendage }\end{array}$ & $\begin{array}{l}\text { Balloon like appendage, structures for keeping air around seeds } \\
\text { Hook or feather like appendage } \\
\text { None of above }\end{array}$ \\
\hline Photosynthesis pathways & $\begin{array}{l}\mathrm{C} 3 \\
\mathrm{C} 4\end{array}$ & $\begin{array}{l}\mathrm{C}_{3} \text { fixation plants } \\
\mathrm{C}_{4} \text { fixation plants }\end{array}$ \\
\hline Growth form & $\begin{array}{l}\text { Woody } \\
\text { Graminoid }\end{array}$ & $\begin{array}{l}\text { Trees, shrubs } \\
\text { True grasses and grass like plants }\end{array}$ \\
\hline
\end{tabular}




\section{RESULTS}

\section{Adjacent land use and local environment of the dumbeongs}

Among the three physical descriptors of the ponds, the area of open-water and water depth were significantly different between the IR and NIR dumbeongs (Tab. 2). The first two principal component axes of the spatial variables explained $70 \%$ of the variation among the dumbeongs (Tab. 3). The first axis LU1 showed negative and positive correlations with the agricultural and forested areas, respectively. According to the variation along LU1, most of the IR and NIR dumbeongs were separated into two groups - adjacent agricultural and forested areas, respectively (Tab. 3, Fig. 2a). The second axis LU2 showed the patterns of adjacent water bodies; however, there was no distinct trend for the management types (Fig. 2a).

The first principal component axis of the water chemical variables, Chem 1 which explained $49 \%$ of the total variation, showed positive intercorrelations between the $\mathrm{EC}$ and concentrations of major cations and nitrogen nutrients (Tab. 3). The DOC and $\mathrm{pH}$ created two independant axes that explained $23 \%$ and $12 \%$ of the variation, respectively. According to the water chemistry PCA ordination, the concentration of water nutrients and EC were relatively high in the NIR dumbeongs (Fig. 2b). However, only two water chemistry variables, EC and sodium ion concentration, were significantly higher in the NIR dumbeongs than in the IR dumbeongs (Tab. 2). Furthermore, the correlations among the PCA axes extracted from land use and water chemistry variables were not significant (Fig. S1, Fig. S2).

\section{Plant functional groups}

The dendrogram shows six plant functional groups classified by the cluster analysis (Fig. 3) and ANOSIM confirmed signifficant differences among the plant functional groups $(\mathrm{R}$ static $=0.87, \mathrm{P}=0.001)$. The plant functional groups (FG1, FG2, FG3, FG4, FG5, and FG6) were mainly defined by four categories of traits - wetland indicator status, life history, vegetative propagation, and

Tab. 2. Land use and local enviroment variables (mean \pm standard error) of the dumbeongs. The land use variables are percentage of cover of agricultural (Agri100, Agri200), forested (Forest100, Forest2000) and water areas (Water100, Water200) within 100 and 200 $\mathrm{m}$ from edges of the dumbeongs, respectively.

\begin{tabular}{|c|c|c|c|}
\hline Variables & IR & NIR & $\mathbf{P}$ \\
\hline \multicolumn{4}{|l|}{ Land uses } \\
\hline Agri100 (\%) & $17.9 \pm 2.4$ & $30.1 \pm 1.8$ & $* *$ \\
\hline Agri200 (\%) & $28.6 \pm 2.9$ & $52.3 \pm 6.6$ & $*$ \\
\hline Forest100 (\%) & $59.0 \pm 6.7$ & $30.7 \pm 8.8$ & $*$ \\
\hline Forest200 (\%) & $46.2 \pm 4.5$ & $42.8 \pm 11.0$ & $\mathrm{~ns}$ \\
\hline Water100 (\%) & $0.4 \pm 0.4$ & $0.4 \pm 0.3$ & $\mathrm{~ns}$ \\
\hline Water200 (\%) & 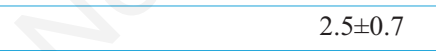 & $1.2 \pm 0.8$ & ns \\
\hline \multicolumn{4}{|c|}{ Local environment } \\
\hline Area $\left(m^{2}\right)$ & $175 \pm 39$ & $222 \pm 46$ & ns \\
\hline Depth (cm) & $82 \pm 9$ & $31 \pm 8$ & $* *$ \\
\hline Open $(\%)$ & $47 \pm 11$ & $4 \pm 1$ & $*$ \\
\hline Conductivity $\left(\mu \mathrm{S} \cdot \mathrm{cm}^{-1}\right)$ & $148 \pm 17$ & $216 \pm 25$ & $*$ \\
\hline $\mathrm{pH}$ & $7.0 \pm 0.1$ & $6.9 \pm 0.1$ & $\mathrm{~ns}$ \\
\hline $\mathrm{Na}^{+}\left(\mathrm{mg} \cdot \mathrm{L}^{-1}\right)$ & $9.93 \pm 1.09$ & $16.11 \pm 1.50$ & $* *$ \\
\hline $\mathrm{K}^{+}\left(\mathrm{mg} \cdot \mathrm{L}^{-1}\right)$ & $2.81 \pm 0.79$ & $5.07 \pm 1.70$ & ns \\
\hline $\mathrm{Mg}^{2+}\left(\mathrm{mg} \cdot \mathrm{L}^{-1}\right)$ & $3.97 \pm 0.56$ & $5.29 \pm 0.79$ & ns \\
\hline $\mathrm{Ca}^{2+}\left(\mathrm{mg} \cdot \mathrm{L}^{-1}\right)$ & $10.75 \pm 2.14$ & $16.00 \pm 1.94$ & $\mathrm{~ns}$ \\
\hline $\mathrm{TN}\left(\mathrm{mg} \cdot \mathrm{L}^{-1}\right)$ & $0.75 \pm 0.22$ & $1.20 \pm 0.41$ & $\mathrm{~ns}$ \\
\hline $\mathrm{NO}_{2}^{-}\left(\mathrm{mg} \cdot \mathrm{L}^{-1}\right)$ & $0.02 \pm 0.02$ & $0.10 \pm 0.05$ & $\mathrm{~ns}$ \\
\hline $\mathrm{NO}_{3-}\left(\mathrm{mg} \cdot \mathrm{L}^{-1}\right)$ & $0.45 \pm 0.23$ & $0.80 \pm 0.40$ & $\mathrm{~ns}$ \\
\hline $\mathrm{DOC}\left(\mathrm{mg} \cdot \mathrm{L}^{-1}\right)$ & $5.66 \pm 0.80$ & $4.89 \pm 0.67$ & ns \\
\hline
\end{tabular}

$I R$, ponds used for irrigation regularly in recent 5 years; NIR, ponds not used for irrigation for more than 5 years; TN, total dissolved nitrogen; DOC, total dissolved organic carbon; Open, the percentage area of open-water surface. Significant differences were tested by Mann-Whitney U-test: $* P<0.05$, ** $P<0.01,{ }^{n s} P>0.05$. 
Tab. 3. Principal component analysis (PCA) results of the land use and water chemistry variables. The land use variables are percentage of cover of agricultural (Agri100, Agri200), forested (Forest100, Forest2000) and water areas (Water100, Water200) within 100 and $200 \mathrm{~m}$ from edges of the dumbeongs, respectively.

\begin{tabular}{|c|c|c|c|c|c|}
\hline \multirow[b]{2}{*}{ Land use variables } & \multicolumn{4}{|c|}{ PCAAxes } & \\
\hline & & LU1 & & LU2 & \\
\hline Agri100 & & -0.57 & & 0.04 & \\
\hline Agri200 & & -0.50 & & -0.05 & \\
\hline Forest100 & & 0.56 & & 0.08 & \\
\hline Forest200 & & 0.27 & & 0.48 & \\
\hline Water100 & & 0.21 & & -0.54 & \\
\hline Water200 & & 0.02 & & -0.68 & \\
\hline Water chemical variables & Chem1 & & Chem2 & & Chem3 \\
\hline Conductivity & 0.41 & & -0.19 & & 0.12 \\
\hline $\mathrm{Mg}^{2+}$ & 0.39 & & -0.22 & & -0.10 \\
\hline $\mathrm{Ca}^{2+}$ & 0.36 & & -0.21 &  & -0.02 \\
\hline $\mathrm{Na}^{+}$ & 0.35 & & -0.14 & & 0.24 \\
\hline $\mathrm{K}^{+}$ & 0.21 & & -0.47 & & -0.15 \\
\hline $\mathrm{TN}$ & 0.35 & & 0.26 & & -0.28 \\
\hline $\mathrm{NO}_{2}^{-}$ & 0.34 & & 0.29 & & -0.22 \\
\hline $\mathrm{NO}_{3}^{-}$ & 0.31 & 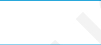 & 0.40 & & -0.16 \\
\hline DOC & 0.03 & 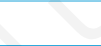 & -0.56 & & -0.32 \\
\hline $\mathrm{pH}$ & 0.12 & & -0.04 & & 0.80 \\
\hline
\end{tabular}

$T N$, total dissolved nitrogen; DOC, total dissolved organic carbon.
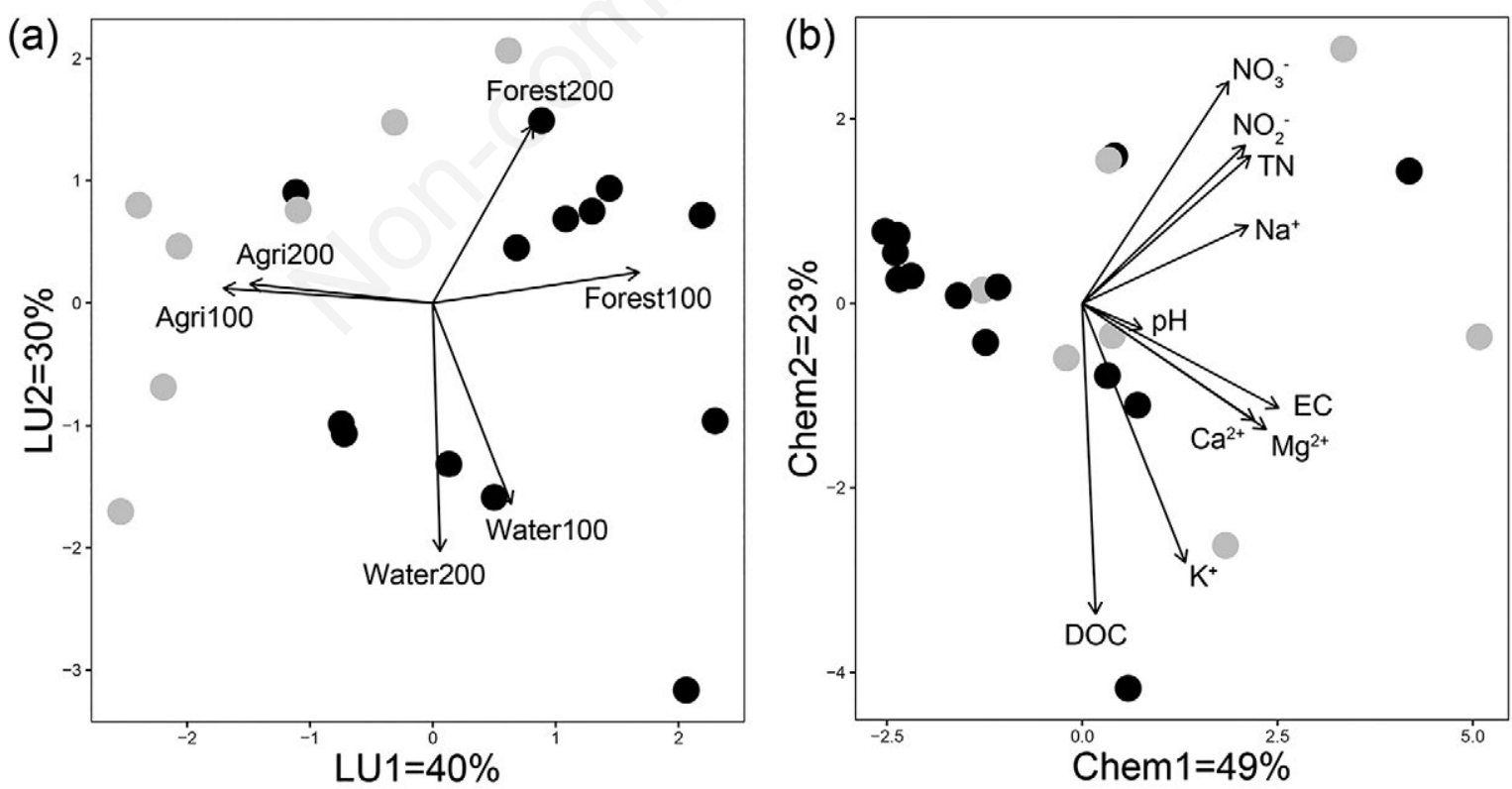

Usage

IR

NIR

Fig. 2. Principal component analysis (PCA) results of the explanatory variables. The PCA plot of (a) land use and (b) water chemistry variables. The land use variables indicate the percentage of cover of agricultural (Agri100, Agri200), forested (Forest100, Forest2000) and water areas (Water100, Water200) within 100 and $200 \mathrm{~m}$ from edges of the dumbeongs, respectively. IR, ponds used for irrigation regularly in recent 5 years; NIR, ponds not used for irrigation for more than 5 years; TN, total dissolved nitrogen; DOC, total dissolved organic carbon; EC, conductivity. 
growth form. The FG1 was characterized by the annual aquatic plant species, such as Lemna perpusilla, Aneilema keisak, and Trapa japonica, which have above-ground vegetative propagation (Fig. 4). The FG1 plant species typically grow near or on the water surface. The FG2 represented annual facultative wetland herbaceous plant species such as Bidens spp. and Persicaria thunbergii, reproducing by seeds (Tab. S2). The FG3 and FG4 were largely composed of facultative graminoid species, and annuals and perennials, respectively; the traits including photosynthetic pathway and seed morphology were significantly different between the groups (Tab. S2). The plant species in FG5 included perennial-emergent macrophytes that reproduce by below-ground vegetative propagules (Fig. 4). The FG5 plant species grow up to approximately $1 \mathrm{~m}$ above the water surface. The FG6 was composed of three woody plant species of the genus Salix.

\section{Composition of plant communities of the dumbeongs}

The plant cover variation within each plant functional group and among the management types are shown as box plots (Fig. 5). The average log-transformed percent cover of the plant functional groups, except FG1, was higher in NIR dumbeongs than in IR dumbeongs. In particular, NIR dumbeongs were dominated by FG5 and FG2 plants. However, only the plant cover of FG2 was statistically different between the two management types of the dumbeongs (Fig. 5). This is because only a few plant species in FG2, such as P. thunbergii, Bidens spp., and Humulus japonicus, were dominant in NIR dumbeongs, indicating the progression of terrestrialization. Only a few plant species were included in FG3 and FG4; however, they were more concentrated in NIR dumbeongs.

The RDA tri-plots represented the correlations among

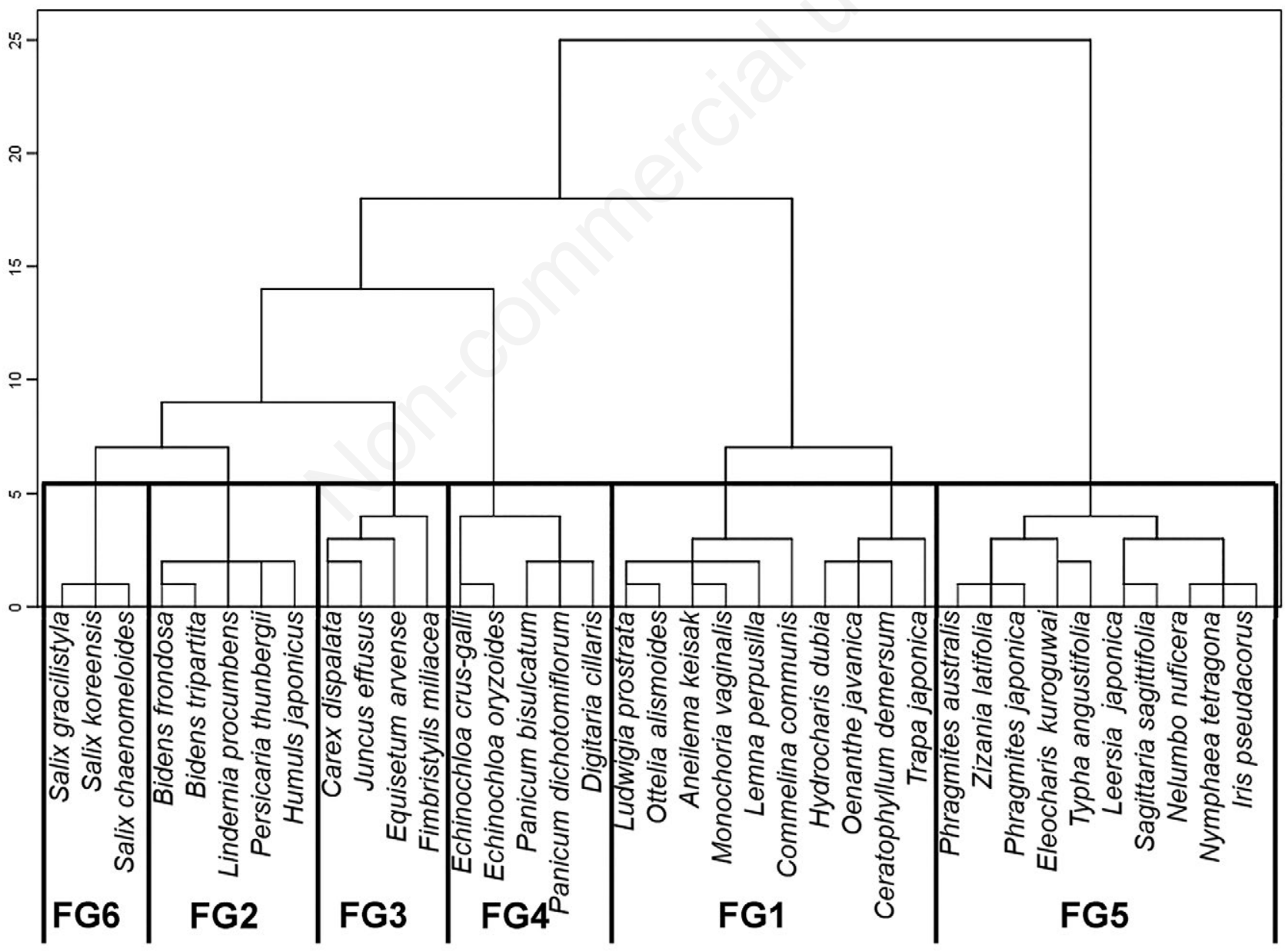

Fig. 3. Dendrogram of 37 dumbeong plant species based on the squared Euclidean distance of the selected traits. Six plant functional groups were classified to examine the relationships between plant community composition and explanatory variables in the dumbeongs. 
plant communities, dumbeongs (plots), and explanatory variables selected by stepwise method (Fig. 6). The first two species-RDA axes explained $17 \%$ of the variation in the plant species data (Fig. 6a). The first axis of the species-RDA was primarily related to the surface area of dumbeongs (Tab. 4). In contrast, the depth correlated negatively with the second axis of the species-RDA. Along the first axis, T. japonica and Leersia japonica dominated some of IR dumbeongs; however, these plants were negatively related to the second axis. P. thunbergii, Typha angustifolia, and Salix koreensis grew densely along both the species-RDA axes. According to the plant functional group level, the first two RDA axes, surface area of open-water and water depth, explained $28 \%$ of the total variation in the plant communities (Fig. 6b). However, Chem2 did not exhibit statistical significance according to the randomized permutation test (Tab. 4). The functional group-RDA presented more relevant explanation than the species-RDA model (Tab. 4). The first axis of functional group-RDA correlated positively with the surface area of open-water. The FG5 and FG1 associated negatively with this axis and this was mainly explained by the surface area of open-water. The second axis of the functional group-RDA showed a strong positive correlation with depth. According to the ordination, FG2, FG3, and FG4 dominated the shallow NIR dumbeongs (Fig. 6b).

\section{DISCUSSION}

\section{Features of dumbeongs and adjacent land use}

The land use of adjacent areas, especially within 100 $\mathrm{m}$ from the edge of the dumbeongs, was used as a determinant of irrigation usage. The water chemistry of the dumbeongs was affected by management practices and location. Although it was not statistically significant (Fig. S1, Fig. S2), the concentration of nutrients and the proportion of croplands and rice paddy fields within 100 $\mathrm{m}$ of the ponds were positively correlated as previous

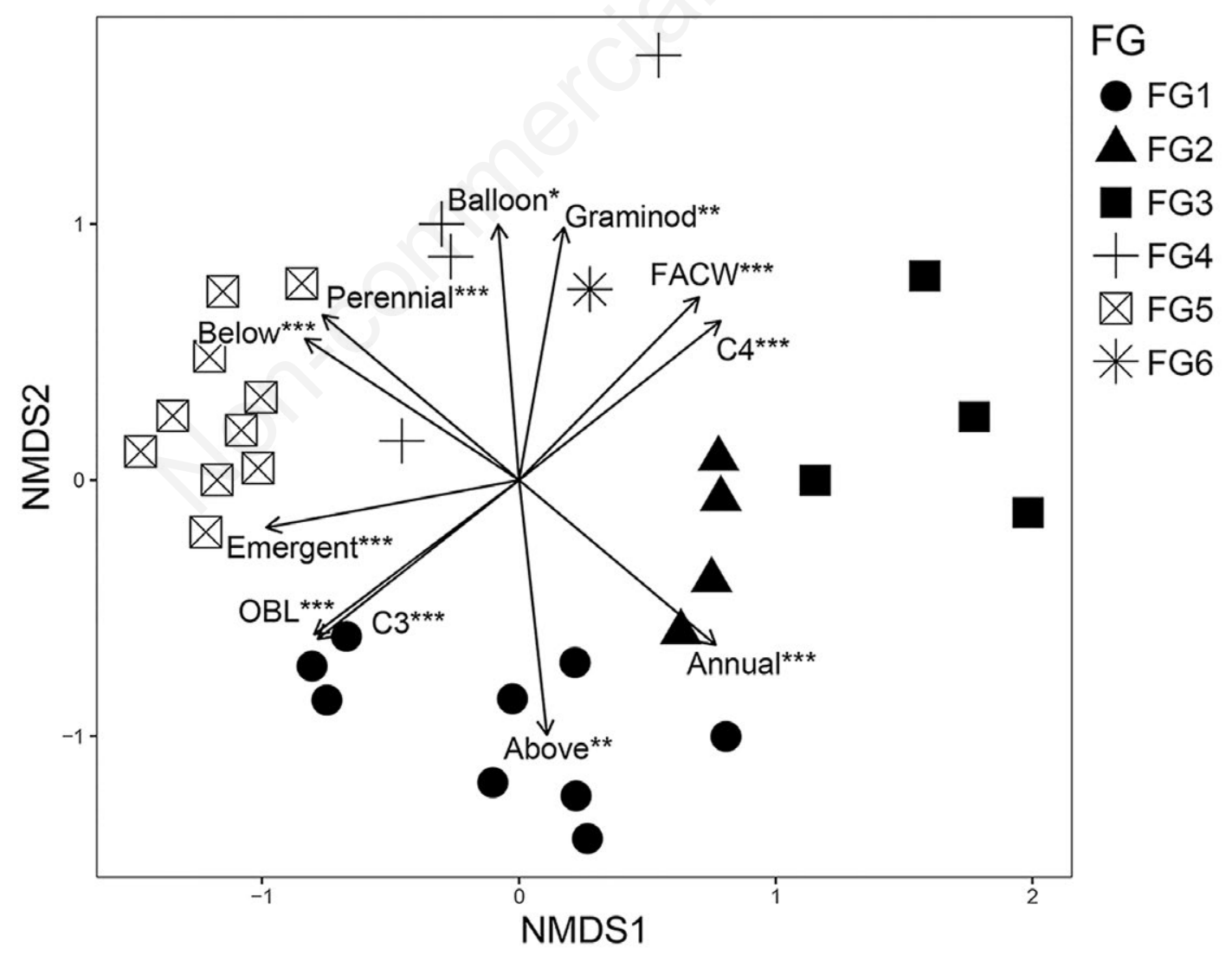

Fig. 4. Non-metric multidimensional scaling (NMDS) plot of species-trait matrix based on the Euclidean distance and fitted vectors of the selected traits. Plant species were plotted as plant functional groups (see Fig. 3). Statistically significant traits among the total selected traits were plotted. The significance of Pearson's correlation between the traits and NMDS axis scores was recorded as follows: $* \mathrm{P}<0.05, * * \mathrm{P}<0.01, * * * \mathrm{P}<0.001$. For the abbreviations of traits, please refer to Category in Tab. 1 . 
studies has shown (Declerck et al., 2006; Akasaka et al., 2010). According to the water chemistry-PCA ordination, most of the IR dumbeongs which were located near forested areas exhibited smaller variation and lower nutrient concentration than the NIR dumbeongs (Fig. 2b).

These results indicate that the accumulated nutrients were periodically removed by drainage in the IR. Furthermore, two of the IR dumbeongs presented unusual water chemistry. One of the IR dumbeong sites exhibited a high concentration of DOC and negligible nitrate and nitrite concentrations. It was completely covered with $L$. perpusilla due to the steep slope of the pond margins. As

Tab. 4. Summary of constrained ordination by RDA. The explanatory variables in the RDA results were chosen by the stepwise selection method. The assigned values of the RDA axes are the correlations between the explanatory variables and RDA axes.

\begin{tabular}{lccccc} 
Variables & RDA1 & RDA2 & adjR $(\%)$ & P \\
\hline $\begin{array}{l}\text { Plant species composition } \\
\text { Area }\end{array}$ & 0.80 & -0.27 & 4 & 1.88 & 0.02 \\
\hline $\begin{array}{l}\text { Depth } \\
\text { Plant functional group composition }\end{array}$ & -0.22 & -0.71 & 5 & 1.69 & 0.04 \\
\hline Open & 0.57 & -0.08 & 9 & 2.35 & 0.01 \\
\hline Depth & 0.06 & -0.61 & 12 & 2.85 & 0.03 \\
\hline Chem2 & -0.26 & 0.31 & 6 & 2.03 & 0.06
\end{tabular}

Open, the percentage area of open-water surface; Chem2, the second principal component axis of water chemical variables (see Tab. 3, Fig. 2).



Fig. 5. Composition of the plant functional groups among the management types of the dumbeongs. Percentage of cover was logtransformed. The box plots represent medians (bold black horizontal line), and $25 \%$ and $75 \%$ quartiles (box perimeters). The small circles away from the vertical lines are outliers. Significant differences were tested by Mann-Whitney $U$-test $(* * \mathrm{P}<0.01)$. 
the site had not been used for irrigation for the past two years, the low DOC consumption rate might have resulted in the high concentration of DOC (Leenheer, 1994; Wang et al., 2013). The other IR dumbeong site, which showed a high concentration of nitrogen nutrients, is being used as a disposal site for cow feces.

The NIR dumbeongs showed a higher concentration of water nutrients and a relatively wide variation in water chemistry (Fig. 2b). This variation can be explained by the difference in the location of the IR and NIR dumbeongs. The IR dumbeongs were located away from adjacent agricultural areas, at higher elevations than the cropfields or rice paddy fields for efficient water supply. Whereas, the three NIR dumbeongs were hydrologically connected to the paddy fields, and showed relatively high concentration of nitrogen. The difference in proximity to rice paddy fields and the output of different nutrients from the fields might have caused large variation in the water chemistry among the dumbeongs. Overall, the concentration of water nutrients was significantly related to the periodic usage for irrigation and the input of nutrients from adjacent rice paddy fields. However, the adjacent land use effects on pond condition was not very clear (Fig. S2). This is probably because we only considered land use in small scale areas with fixed-radius. Land use in the each pond's catchement which can reflect local characteristics such as pond area, pond tophography, and local climate should be considred in future studies (Novicmek et al., 2016).

\section{Grouping of the dumbeong plant species}

The categorization of singular traits helps to understand complex communities with characteristics corresponding to environmental conditions (McGill et al., 2006). Recent studies on the composition of plant communities in ponds have used functional categorization by traits, such as plant morphology and affinity for water, for better prediction of community composition (Gallego et al., 2014; Caria et al., 2015; McCann, 2015). However, over-simplification in the categorization of species limits the scope for scientific interpretation. Thus, we classified the dumbeong plant species according to seven response traits to reveal the relationship between the plant communities and disturbances or environmental gradients (Hooper et al., 2005).

The plant functional groups were defined by traits, including life history, wetland indicator status, presence of vegetative propagules, and growth form (Tab. S2, Fig. 4). Each plant functional group is characterized by distinct dominant species. For example, FG1 is dominated by annual aquatic plants, although a few perennial plant species and one non-aquatic plant species are included (Tab. S2). The plant functional groups were classified by
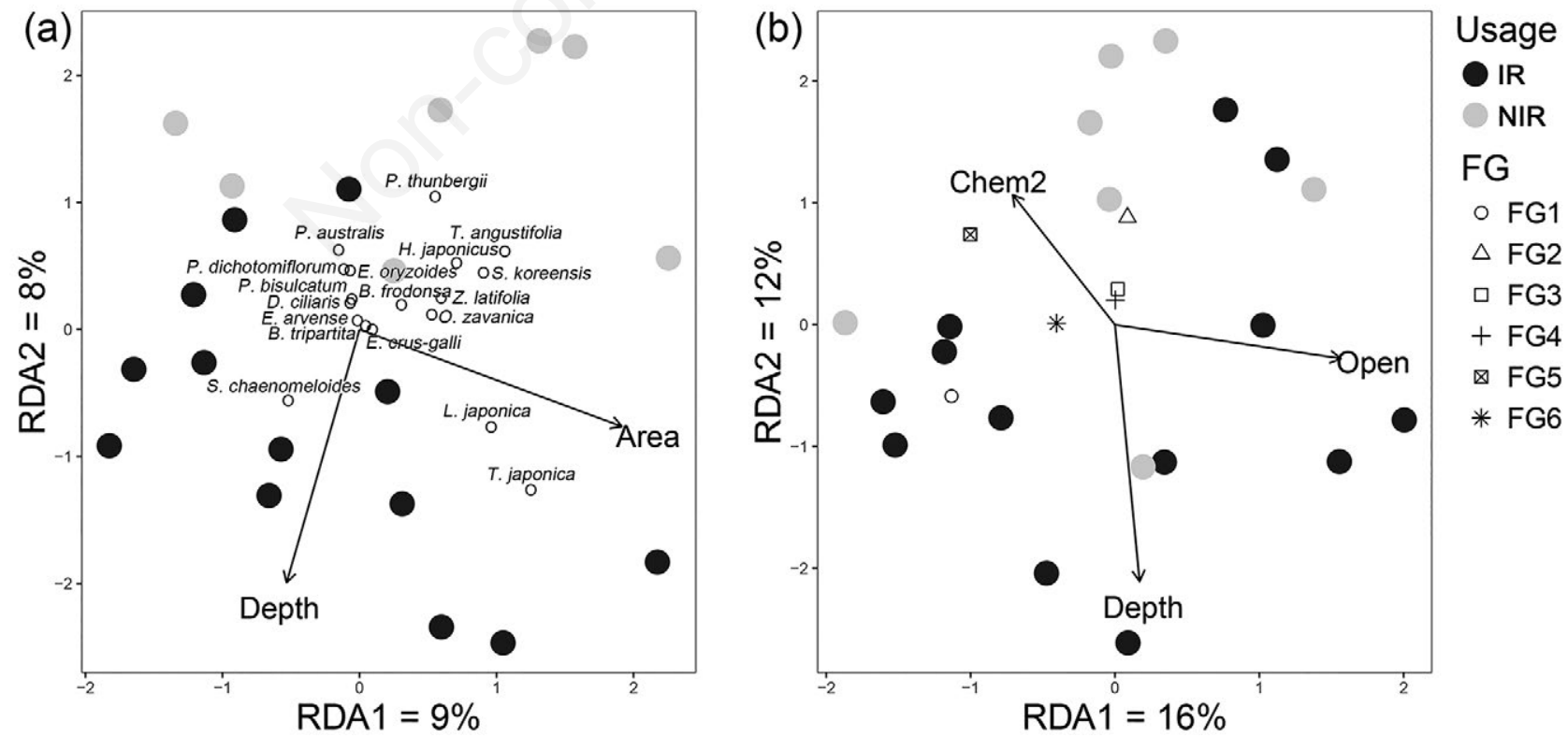

Fig. 6. Redundancy analysis (RDA) plot of (a) plant species and (b) plant functional groups. The plant species for which the RDA axes explained more than $10 \%$ of their total variation were plotted. IR, ponds used for irrigation regularly in recent 5 years; NIR, ponds not used for irrigation for more than 5 years; FG, plant functional groups (see Fig. 3); Open, the percentage area of open-water surface; Chem2, the second principal component axis of water chemical variables (see Tab. 3, Fig. 2). 
the Euclidean distance to reflect ecological distance and to avoid artificial classification. Therefore, their diversity reflected the complex composition of traits within the observed dumbeong plant communities. While FG1 and FG5 aquatic plants that are classified as emergent species share certain similarity in terms of the growth form, it was notable that most FG1 plants tend to grow shorter than those of FG5. The use of multiple sets of traits can potentially lead to similar non-selected traits within each plant functional group. This is probably because multiple correlated traits also reveal pleiotropic changes among species (Schlichting, 1986). Nevertheless, continuous functional traits are important characteristics in a community assembly and form a basis for researchers to build quantitative prediction models in community ecology studies (Swenson and Weiser, 2010; Byun et al., 2013; Laughlin, 2014). Therefore, future studies can classify the plant species by considering continuous functional traits such as specific leaf area and seed mass.

\section{Composition of plant communities}

According to the species-RDA results, area and depth were the significant predictors of plant composition in the dumbeongs. The area was positively correlated with $L$. japonica and T. japonica in the IR dumbeongs (Fig. 6a). The relationship between area and plant species in ponds is generally explained by the development of vegetation in the marginal area (Edvardsen and Økland, 2006). However, L. japonica and T. japonica inhabited both central and marginal areas of the dumbeongs, and there was no consistent co-occurrence of facultative wetland plant species, such as $P$. thunbergii and Bidens spp. that generally grow in the marginal spaces of ponds; the latter three species exhibited partially positive correlation with the first axis of the species-RDA in the NIR dumbeongs with a gentle slope formed by sedimentation over the past 10-30 years (Fig. 6b). Thus, the total surface area, size of the shallow marginal area, and development of marginal vegetation can be positively correlated in the NIR dumbeongs. However, the interviews with the pond owners suggested that T. japonica was introduced into the IR dumbeongs when the water was supplied from an adjacent reservoir or when the owners planted it as a food source. Because of the complexity introduced by management practices, it is thus difficult to conclude the effect of the adjacent area on the species composition of the dumbeongs.

At the species level, the water depth significantly negatively correlated with several species, including $P$. thunbergii and H. japonica (FG2), S. koreensis (FG6), and T. angustifolia (FG5). At the functional group level, FG2, FG3, and FG4 showed a convergent trend, and were similarly negatively correlated with the depth of water (Fig. 6b). Thus, the depth of water explained the variation in the plant functional groups mainly by predicting the convergent trend according to the three functional groups, which were largely represented by early-succession plant species in the abandoned rice paddies (Lee et al., 2002). Conversely, FG5 and FG6 were more significantly associated with the open-water surface area than with the water depth. Generally, in abandoned rice paddy fields, the perennial-aquatic plant species (FG5) and Salix species (FG6) represented the plant communities at the intermediate and later stages of succession, respectively (Lee et al., 2002).

Our results showed that the plant communities of NIR dumbeongs were in the process of succession. Although the water depth and plant cover of FG5 significantly differed between IR and NIR dumbeongs, the plant functional group-RDA model exhibited a low correlation between depth and FG5 (Fig. 6b). There are two possible explanations for this result. First, the typical plant species in FG5 easily occupy wetlands through vegetative propagation (Boutin and Keddy, 1993; Mitsch et al., 2012; Sayer et al., 2012). Second, transplantation was prevalent among the pond owners, which seemed to affect the plant community composition. For example, six species, including two Salix species, T. japonica, Nelumbo nucifera, Nymphaea tetragona, and Iris pseudacorus, were intentionally planted for various purposes (Tab. S3). In particular, three planted species of floating-leaved macrophytes with large leaves and four species that rapidly reduce the open-water area of dumbeongs belonged to FG5. Furthermore, FG1 plants, including $T$. japonica and fast-growing annual aquatic plant species, dominated some of the IR dumbeongs (Figs. 5 and 6).

The open-water surface area is not an environmental filter that determines the composition of plant communities (Van der Valk, 1981; Keddy et al., 1992). However, studies have discussed the importance of maintaining moderate levels of open-water to allow aquatic insects to breed and to retain the diversity of plants (Chester and Robson, 2013). Extremely large surface areas of water, as frequently observed in IR dumbeongs, lack shelter and breeding places for amphibians and macroinvertebrates (Gioria et al., 2010; Landi et al., 2012). Although planting can increase the diversity of plant species, it can lead to low alpha diversity of macrophyte species due to shading (Hassall et al., 2011; Sayer et al., 2012; Pier et al., 2015). Thus, proper management is required to enhance biodiversity by controlling some FG1 and FG5 plant species that are well adapted to environmental disturbances.

Studies have discussed the influence of water chemistry on the composition of plants in ponds (Capers et al., 2010; Del Pozo et al., 2010; Kim et al., 2011). Our findings showed that the concentration of water nutrients was relatively high in IR dumbeongs, however, there is a 
marginal relationship between water chemistry and plant composition. Although Chem2, which was selected in the stepwise selection method when we developed RDA models, presented large variation in DOC and $\mathrm{NO}_{3}{ }^{-}$ among NIR dumbeongs (Fig. 2b), the difference was not significant in the post-hoc test (Tab. 4). Thus, environmental filtering by water chemistry did not significantly affect the dumbeong plant composition.

Our study identified three types of plant communities in five NIR dumbeongs that contained no introduced plant species: (1) FG2 dominant, (2) FG5 dominant, and (3) FG3 and FG4 dominant. The concentration of $\mathrm{NO}_{3}^{-}$was considerably lower (about one-tenth) in types (1) and (3), than in type (2). However, each functional group was composed of wetland plant species related to different ranges of water quality conditions. For example, in FG5, T. angustifolia, Sagittaria sagittifolia, and L. japonica are indicators of nutrient-rich habitat, whereas Phragmites japonica and Eleocharis kuroguwai are sensitive to eutrophic conditions (Penning et al., 2008; Seo et al., 2014). As we did not select the functional traits representing nutrient conditions, the effect of Chem 2 as an environmental filter on plant community composition at functional group levels was blurred. Furthermore, the species planted by the pond owners, regardless of the nutrient conditions, cannot be ignored. Consequently, the physiochemical environment and plant communities across the dumbeongs appeared to be independently determined by anthropogenic influences, especially the use of adjacent land and ponds for irrigation.

\section{CONCLUSIONS}

Management practices affected the environment and plant composition of dumbeongs. The use of dumbeongs for irrigation generally prevented the accumulation of nutrients that might have made the ponds shallow. However, extremely high nutrient accumulation was detected in the IR dumbeongs, owing to the nonconventional management practices. In contrast, the NIR dumbeongs were more affected by land use in the adjacent rice paddies than by the management practices of the dumbeongs. Although the composition of plant species and plant functional groups did not correlate with the water chemistry variables, the predictors explained more variation in the plant functional groups than in the plant species.

Our approach showed that the plant functional groups predict plant composition in the dumbeongs better than the plant species. One limitation of the study is that only a few characteristics of the plant functional groups, representing the degree of adaptation to aquatic conditions, were strongly related to plant composition of the dumbeongs. Thus, future studies should consider continuous functional traits when building plant functional groups to better understand the composition of plant communities and to develop an appropriate conservation plan for dumbeongs.

Overall, the findings of the present study show that management practices, including irrigation usage, planting, and plant removal, are crucial to improve the ecological function of dumbeongs as wetland habitats in the agricultural landscapes in Korea. In addition, analysis based on plant functional groups rather than plant species can be more applicable in the management of biodiversity in dumbeongs, as it can provide a clear view of the ecological niche of plant communities in dumbeongs.

\section{ACKNOWLEDGMENTS}

The present study was supported by the Basic Science Research Program through the National Research Foundation of Korea, funded by the Ministry of Science, ICT, and Future Planning (grant number NRF2015R1A2A2A03007350). The functional trait data of our study has been supported by the Try initiative on plant traits (http://www.try-db.org). This initiative and database is hosted, developed and maintained by Jens Kattge and Gerhard Bönisch (Max Planck Institute for Biogeochemistry, Jena, Germany). TRY has been supported by DIVERSITAS core project bioDISCOVERY, the IGBP, the Global Land Project, the UK Natural Environment Research Council (NERC) through its program QUEST (Quantifying and Understanding the Earth System) and the French programs 'Climat, Environnement, Société', and the French Foundation for Biodiversity Research (FRB). We appreciate all the owners of dumbeongs who allowed us to investigate their ponds. We are also grateful to Yuri Cho, Minjoo Lee, Minji Son, and Bumsuk Seo for helpful advice on the manuscript. Finally, the authors thank Junyong Song, Donguk Han, Eunjeong Lee, Eunju Lee, Hyunyoung Chung, and Minjeong Cha for their great help with field and laboratory work.

\section{REFERENCES}

Akasaka M, Takamura N, Mitsuhashi H, Kadono Y, 2010. Effects of land use on aquatic macrophyte diversity and water quality of ponds. Freshwater Biol. 55:909-922.

Alahuhta J, Aroviita J, 2016. Quantifying the relative importance of natural variables, human disturbance and spatial processes in ecological status indicators of boreal lakes. Ecol. Indic. 63:240-248.

Benton TG, Vickery JA, Wilson JD, 2003. Farmland biodiversity: is habitat heterogeneity the key? Trends Ecol. Evol. 18:182-188.

Boutin C, Keddy PA, 1993. A functional classification of wetland plants. J. Veg. Sci. 4:591-600. 
Byun C, de Blois S, Brisson J, 2013. Plant functional group identity and diversity determine biotic resistance to invasion by an exotic grass. J. Ecol. 101:128-139.

Capers RS, Selsky R, Bugbee GJ, 2010. The relative importance of local conditions and regional processes in structuring aquatic plant communities. Freshwater Biol. 55:952-966.

Caria MC, Capra GF, Buondonno A, Seddaiu G, Vacca S, Bagella S, 2015. Small-scale patterns of plant functional types and soil features within Mediterranean temporary ponds. Plant Biosyst. 149:384-394.

Casas JJ, Toja J, Peñalver P, Juan M, León D, Fuentes-Rodríguez F, Gallego I, Fenoy E, Pérez-Martínez C, Sánchez P, Bonachela S, Elorrieta MA, 2012. Farm ponds as potential complementary habitats to natural wetlands in a mediterranean region. Wetlands 32:161-174.

Chester ET, Robson BJ, 2013. Anthropogenic refuges for freshwater biodiversity: Their ecological characteristics and management. Biol. Conserv. 66:64-75.

Cho KJ, Oh YJ, Kang KK, Han MS, Na YE, Kim M, Choe LJ, Kim $\mathrm{MH}, 2013$. Occurrence and distribution of $\mathrm{C}_{4}$ plants under diverse agricultural field types in Korea. [Article in Korean with an English abstract]. Korean J. Agricult. Forest Meteorol. 15:85-101.

Choe LJ, Han MS, Kim M, Cho KJ, Kang KK, Na YE, Km MH, 2013. Characteristics communities structure of benthic macroinvertebrates at irrigation ponds, within paddy field.[article in Korean with an English abstract]. Korean J. Environm. Agricult. 32:304-314.

Choe LJ, Cho KJ, Han MS, Kim MK, Choi SK, Bang HS, Eo J, $\mathrm{Na}$ YE, Kim MH, 2016. Benthic macroinvertebrate biodiversity improved with irrigation ponds linked to a rice paddy field. Entomol. Res. 46:70-79.

Choung Y, Lee W, Cho KH, Joo KY, Min BM, Hyun JO, Lee $\mathrm{KS}, 2012$. [Categorizing vascular plants species occuring in wetland ecosystems of the Korean Peninsula].[Book in Korean]. Center for Aquatic Ecosystem Restoration, Chuncheon.

Declerck S, De Bie T, Ercken D, Hampel H, Schrijvers S, VanWichelen J, Gillard V, Mandiki R, Losson B, Bauwens D, Keijers S, Vyvermand, W, Goddeeris B, De meester L, Brendonck L, Martens K, 2006. Ecological characteristics of small farmland ponds: Associations with land use practices at multiple spatial scales. Biol. Conserv. 131:523-532.

Deegan BM, White SD, Ganf GG, 2007. The influence of water level fluctuations on the growth of four emergent macrophyte species. Aquat. Bot. 86:309-315.

Del Pozo R, Fernández-Aláez C, Fernández-Aláez M, 2010. An assessment of macrophyte community metrics in the determination of the ecological condition and total phosphorus concentration of Mediterranean ponds. Aquat. Bot. 92:55-62.

Downing AL, 2005. Relative effects of species composition and richness on ecosystem properties in ponds. Ecology 86:701715.

Downing AL, Leibold MA, 2002. Ecosystem consequences of species richness and composition in pond food webs. Nature 416:837-841.

Edvardsen A, Økland RH, 2006. Variation in plant species richness in and adjacent to 64 ponds in SE Norwegian agricultural landscapes. Aquat. Bot. 85:79-91.
eFloras, 2016. eFloras.org. Available from: http://efloras.org/ index.aspx

Gallego I, Davidson TA, Jeppesen E, Pérez-Martínez C, Fuentes-Rodríguez F, Juan M, Casus JJ, 2014. Disturbance from pond management obscures local and regional drivers of assemblages of primary producers. Freshwater Biol. 59:1406-1422.

Gichuki J, Triest L, Dehairs F, 2001. The use of sTab. carbon isotopes as tracers of ecosystem functioning in contrasting wetland ecosystems of Lake Victoria, Kenya. Hydrobiologia 458: 91-97.

Gioria M, Schaffers A, Bacaro G, Feehan J, 2010. The conservation value of farmland ponds: Predicting water beetle assemblages using vascular plants as a surrogate group. Biol. Conserv. 143:1125-1133.

Hansson LA, Brönmark C, Nilsson PA, Åbjörnsson K, 2005. Conflicting demands on wetland ecosystem services: Nutrient retention, biodiversity or both? Freshwater Biol. 50:705-714.

Hassall C, Anderson S, 2015. Stormwater ponds can contain comparable biodiversity to unmanaged wetlands in urban areas. Hydrobiologia 745:137-149.

Hassall C, Hollinshead J, Hull A, 2011. Environmental correlates of plant and invertebrate species richness in ponds. Biodivers. Conserv. 20:3189-3222.

Hooper DU, Chapin III FS, Ewel JJ, 2005. Effects of biodiversity on ecosystem functioning: a consensus of current knowledge. Ecol. Monogr .75:3-35.

Huang SL, Lee YC, Budd WW, Yang MC, 2012. Analysis of changes in farm pond network connectivity in the peri-urban landscape of the taoyuan area, taiwan. Environ. Manage. 49:915-928.

Katori M, Nomura K, Yoneda K, 2002. Propagation of flowering lotus (Nelumbo nucifera Gaertn) by rhizome straps, without enlarged rhizomes. Jpn. J. Trop. Agr. 46:195-197.

Kattge J, Díaz S, Lavorel S, Prentice IC, Leadley P, Bönisch G, Garnier E, Westoby M, Reich PB, Wright IJ, Cornelissen JH, Violle C, Harrison SP, van Bodegom PM, Reichstein M, Enquist BJ, Soudzilovskaia NA, Ackerly DD, Anand M, Atkin O, Bahn M, Baker TR, Baldocchi D, Bekker R, Blanco C, Blonder B, Bond WJ, Bradstock R, Bunker DE, Casanoves F, Cavender-Bares J, Chambers JQ, Chapin FS, Chave J, Coomes D, Cornwell WK, Craine JM, Dobrin BH, Duarte L, Durka W, Elser J, Esser G, Estiarte M, Fagan WF, Fang J, Fernández-Méndez F, Fidelis A, Finegan B, Flores O, Ford H, Frank D, Freschet GT, Fyllas NM, Gallagher RV, Green WA, Gutierrez AG, Hickler T, Higgins S, Hodgson JG, Jalili A, Jansen S, Joly C, Kerkhoff AJ, Kirkup D, Kitajima K, Kleyer M, Klotz S, Knops JMH, Kramer K, Kühn I, Kurokawa H, Laughlin D, Lee TD, Leishman M, Lens F, Lenz T, Lewis SL, Lloyd J, Llusià J, Louault F, Ma S, Mahecha MD, Manning P, Massad T, Medlyn B, Messier J, Moles AT, Müller SC, Nadrowski K, Naeem S, Niinemets Ü, Nöllert S, Nüske A, Ogaya R, Oleksyn J, Onipchenko VG, Onoda Y, Ordoñez J, Overbeck G, Ozinga WA, Patiño S, Paula S, Pausas JG, Peñuelas J, Phillips OL, Pillar V, Poorter H, Poorter L, Poschlod P, Prinzing A, Proulx R, Rammig A, Reinsch S, Reu B, Sack L, Salgado-Negret B, Sardans J, Shiodera S, Shipley B, Siefert A, Sosinski E, Soussana JF, Swaine E, Swenson N, Thompson K, Thornton 
P, Waldram M, Weiher E, White M, White S, Wright SJ, Yguel B, Zaehle S, Zanne AE, Wirth C, 2011. TRY - a global database of plant traits. Glob. Chang Biol. 17:2905-2935.

Keddy PA, Journal S, Apr N, Paul A, 1992. Assembly and response rules: two goals for predictive community. Ecology J. Veg. Sci. 3:157-164.

Kim S, Kim J, Kim J, 2011. [Water characteristics and similarity analysis of wetland plant communities in 4 types of small irrigation ponds in western Civilian Control Zone in Korea].[Article in Korean with English abstract]. J. Wetl. Res. W13:581-591.

Kleyer M, Bekker RM, Knevel IC, Bakker JP, Thompson K, Sonnenschein M, Poschlod P, van Groenendael JM, Klimeš L, Klimešová J, Klotz S, Rusch GM, Hermy M, Adriaens D, Boedeltje G, Bossuyt B, Dannemann A, Endels P, Götzenberger L, Hodgson JG, Jackel AK, Ku“hn I, Kunzmann D, Ozinga WA, Römermann C, Stadler M, Schlegelmilch J, Steendam HJ, Tackenberg O, Wilmann B, Cornelissen HJC, Eriksson O, Garnier E, Peco B, 2008. The LEDA Traitbase: a database of life-history traits of the Northwest European flora. J. Ecol. 96:1266-1274.

Korea National Arboretum, 2016. Korea Biodiversity Information System. Available from: http://www.nature.go.kr/

Kühn I, Durka W, Klotz S, 2004. BiolFlor: a new plant-trait database as a tool for plant invasion ecology. Divers. Distrib. 10:363-365.

Laboratory of Wild Plant Science, 2014. Naturalized plants in Japan: seed image database. Research Institute for Bioresources of Okayama University. Available from: http://www.rib.okayamau.ac.jp/wild/okayama kika v2/Seed-image-database.html

Landi M, Piazzini S, Nucci A, Saveri C, Angiolini C, 2012. Can macrophytes be a surrogate for amphibians and physicochemical features in pond classifications? Aquat. Bot. 101:1-7.

Laughlin DC, 2014. The intrinsic dimensionality of plant traits and its relevance to community assembly. J. Ecol. 102:186-193.

Lee CS, You NH, Robinson GR, 2002. Secondary succession and natural habitat restoration in abandoned rice fields of Central Korea. Restor. Ecol. 10:306-314.

Leenheer JA, 1994. Chemistry of dissolved organic matter in rivers, lakes, and reservoirs, p. 195-221. In: L.A. Baker (ed.), Environmental chemistry of lakes and reservoirs American Chemical Society, Washington.

Legendre P, Legendre L, 2012. Numerical ecology. Elsevier, Amsterdam.

Lemmens P, Mergeay J, de Bie T, Van Wichelen J, De Meester L, Declerck SAJ, 2013. How to maximally support local and regional biodiversity in applied conservation? Insights from pond management. PLoS One 8:1-13.

McCann MJ, 2015. Local and regional determinants of an uncommon functional group in freshwater lakes and ponds. PLoS One 10:1-15.

McGill BJ, Enquist BJ, Weiher E, Westoby M, 2006. Rebuilding community ecology from functional traits. Trends Ecol. Evol. 21:178-85.

Michel N, Burel F, Legendre P, Butet A, 2007. Role of habitat and landscape in structuring small mammal assemblages in hedgerow networks of contrasted farming landscapes in Brittany, France. Landsc. Ecol. 22:1241-1253.

Mitsch WJ, Wilson RFRF, 1996. Improving the success of wetland creation and restoration with know-how, time, and self-design. Ecol. Appl. 6:77-83.

Mitsch WJ, Zhang L, Stefanik KC, Nahlik AM, Anderson CJ, Bernal B, Hernandez M, Song K, 2012. Creating wetlands: Primary succession, water quality changes, and self-design over 15 years. Bioscience 62:237-250.

Morishima H, Oka HI, 1976. The impact of copper pollution on weed communities in Japanese rice fields. Agr. Ecosyst. Environ. 3:131-45.

Mouillot D, Graham NAJ, Villéger S, Mason NWM, Bellwood DR, 2013. A functional approach reveals community responses to disturbances. Trends Ecol. Evol. 28:167-77.

National Geographic Information Institute, 2014. Land-use of Seocheon. Available from: http://map.ngii.go.kr/mn/ mainPage.do

Oertli B, Biggs J, Céréghino R, Grillas P, Joly P, Lachavanne JB, 2005. Conservation and monitoring of pond biodiversity1: Introduction. Aquat. Conserv. 15:535-540.

Oksanen J, Blanchet FG, Kindt R, Legendre P, Minchin PR, O'Hara RB, 2016. vegan: Community Ecology Package. R Package, ver. 2.4-1. Available from: http://github.com/ vegandevs/vegan

Penning, WE, Mjelde M, Dudley B, Hellsten S, Hanganu J, Kolada A, van den Berg M, Poikane S, Phillips G, Willby N, Ecke F, 2008. Classifying aquatic macrophytes as indicators of eutrophication in European lakes. Aquat. Ecol. 237-251.

Pier BM, Dresser BR, Lee JJ, Boylen CW, Nierzwicki-Bauer SA, 2015. Ecological analysis before and after planting in a constructed wetland in the adirondacks. Wetlands 35:611-624.

Raven JA, 1992. The physiology of Salix. Proc. R. Soc. Edinb. B. 98:49-62.

R Development Core Team R, 2016. R: a language and environment for statistical computing.: $\mathrm{R}$ ver. 3.2. 3. $\mathrm{R}$ Foundation for Statistical Computing, Vienna.

Santi E, Mari E, Piazzini S, Renzi M, Bacaro G, Maccherini S, 2010. Dependence of animal diversity on plant diversity and environmental factors in farmland ponds. Community Ecol. 11:232-241.

Sayer C, Andrews K, Shilland E, Edmonds N, Edmonds-Brown R, Patmore I, Emson D, Axmacher J, 2012. The role of pond management for biodiversity conservation in an agricultural landscape. Aquat. Conserv. 22:626-638.

Schlichting CD, 1986. The evolution of phenotypic plasticity in plants. Annu. Rev. Ecol. Evol. Syst.17:667-693.

Seo A, Lee K, Kim B, Choung Y, 2014. Classifying plant species indicators of eutrophication in Korean lakes. Paddy Water Environ. 12:29-40.

Seocheon County, 2016. The weather of Seocheon. Available from: http://www.seocheon.go.kr/kor.do

Søndergaard M, Jeppesen E, Jensen JP, 2005. Pond or lake: does it make any difference? Arch. Hydrobiol. 162:143-165.

Swenson NG, Weiser MD, 2010. Plant geography upon the basis of functional traits: An example from eastern North American trees. Ecology 91:2234-2241.

USDA/NRCS, 2016. The PLANTS database. National Plant Data Center. U.S. Department of Agriculture Natural Resource Conservation Service. Available from: http://plants.usda.gov

Van der Valk AG, 1981. Succession in wetlands: A Gleasonian approach. Ecology 62:688-696. 
Van TK, Haller WT, Bowes G, 1976. Comparison of the photosynthetic characteristics of three submersed aquatic plants. Plant Physiol. 58:761-768.

Villéger S, Novack-Gottshall PM, Mouillot D, 2011. The multidimensionality of the niche reveals functional diversity changes in benthic marine biotas across geological time. Ecol. Lett. 14:561-568.

Wang LL, Song CC, Yang GS, 2013. Dissolved organic carbon characteristics in surface ponds from contrasting wetland ecosystems: A case study in the Sanjiang Plain, Northeast China. Hydrol. Earth Syst. Sc. 17:371-378.
Williams P, Whitfield M, Biggs J, Bray S, Fox G, Nicolet P, Sear D, 2004. Comparative biodiversity of rivers, streams, ditches and ponds in an agricultural landscape in Southern England. Biol. Conserv. 115:329-341.

Wood PJ, Greenwood MT, Agnew MD, 2003. Pond biodiversity and habitat loss in the UK. Area 35:206-216.

Zhang Y, Wang R, Kaplan D, Liu J, 2015. Which components of plant diversity are most correlated with ecosystem properties? A case study in a restored wetland in northern China. Ecol. Indic. 49:228-236. 